\title{
PENGEMBANGAN MEDIA PEMBELAJARAN KARTU BERGAMBAR BERBASIS PETA KONSEP POKOK BAHASAN JAMUR DI SMP NEGERI 16 KOTA KUPANG TAHUN AJARAN 2018/2019
}

\section{(DEVELOPMENT OF LEARNING MEDIA FOR PICTURE CARDS BASED ON THE CONCEPT MAP OF MUSHROOMS AT SMP NEGERI 16 KOTA KUPANG ACADEMIC YEAR 2018/2019)}

\author{
Daud Serang, Fransina Th. Nomleni' ${ }^{2}$, Paulus Tnunay ${ }^{3}$, \\ 1,2,3, Program StudiPendidikan Biologi Fakultas Keguruan dan IImu Pendidikan, Universitas Kristen \\ Artha Wacana -NTT
}

Corresponding author: nomlenifince@gmail.com

\begin{abstract}
ABSTRAK
Permasalahan yang ditemukan adalah bahwa masih kurangnya media pembelajaran dalam mendukung proses pembelajaran. Penelitian ini bertujuan untuk mengembangkan produk media kartu bergambar yang layak digunakan pada pokok bahasan jamur. Model pengembangan yang digunakan dalam penelitian ini adalah Model ADDIE (Analisys, Design, Development, Implementation, danEvaluation). Presentasi hasil penelitian ini diperoleh dari hasil uji coba ahli materi $94 \%$, dengan kualifikasi baik,uji ahli desain $94 \%$, uji ahli media $97 \%$, uji kelompok kecil $79 \%$ dan uji kelompok besar $86 \%$. Berdasarkan data para ahli dapat diketahui bahwa menurut ahli materi, ahli desain, ahli media, uji coba kelompok kecil dan uji coba kelompok besar dengan jumlah presentasi keseluruhannya adalah $90 \%$. Persentase penilaian menunjukkan adanya respon positif terhadap Media Pembelajaran kartu bergambar yang dikembangkan, sehingga menunjukkan bahwa bentuk gambar yang dikembangkan layak digunakan sebagai Media pembelajaran karena bentuk Media Pembelajaran kartu bergambar tersebut sesuai dengan tujuan pembelajaran. Hal ini dikarenakan bentuk Media Pembelajaran kartu bergambar yang dikembangkan memiliki kelebihan tersendiri, dimana karakter gambar yang terdapat pada media kartu bergambar dapat menarik perhatian siswa sehingga materi pembelajaran akan lebih mudah dipahami siswa serta dapat membantu guru untuk mengajar materi Jamur.
\end{abstract}

Kata Kunci : Pengembangan, Media Pembelajaran, Kartu Bergambar

\begin{abstract}
This study aims to develop a suitable picture card media product for use on the subject of mushrooms. The development model used in this study is the ADDIE Model (Analysis, Design, Development, Implementation, and Evaluation). The presentation of the results of this study was obtained from the results of the test of material experts $94 \%$, with good qualifications, design expert test $94 \%$, media expert test $97 \%$, small group test $79 \%$ and large group test $86 \%$. Based on data from experts, it can be seen that according to material experts, design experts, media experts, small group trials and large group trials with the total number of presentations is $90 \%$. The percentage of the assessment shows a positive response to the learning media for picture cards that are developed, thus indicating that the form of the image developed is suitable for use as a learning media because the form of learning media for picture cards is in accordance with the learning objectives. This is because the form of picture card Learning Media that has been developed has its own advantages, where the image characters contained in the picture card media can attract students' attention so that the learning material will be easier for students to understand and can help teachers to teach mushroom material.
\end{abstract}

Keywords: Development, Learning Media, Picture Cards 


\section{PENDAHULUAN}

Media adalah segala sesuatu yang digunakan untuk menyalurkan pesan dari pengirim ke penerima sehingga dapat merangsang pikiran, perasaan, perhatian dan minat siswa sedemikian rupa sehingga proses belajar terjadi (Sadiman, 2012). Maka dapat dikatakan bahwa media merupakan salah satu komponen yang sangat penting dalam proses pembelajaran karena membawa pengaruh yang signifikan dalam mencapai tujuan pembelajaran. Hal ini sesuai dengan pendapat Azhar (2016) yang menyatakan bahwa salah satu manfaat praktis dari penggunaan media pembelajaran adalah dapat memberikan kesamaan pengalaman kepada siswa tentang peristiwaperistiwa di lingkungan mereka, serta memungkinkan terjadinya interaksi langsung dengan guru, masyarakat dan lingkungannya.

Dalam proses belajar mengajar kehadiran media mempunyai arti penting. Karena dalam proses pembelajaran terdapat ketidakjelasan bahan yang disampaikan dapat dibantu dengan menghadirkan media sebagai perantara kurikulum, bahan ajar (Apriliani dkk, 2013). Salah satu media yang dapat digunakan adalah media kartu bergambar. Media kartu bergambar adalah kartu tebal berbentuk persegi panjang yang memuat gambar tunggal yang menyajikan ilustrasi yang hampir sama dengan kenyataan suatu objek dan situasi (Prayogo, dkk, 2015). Dengan demikian penggunaan media kartu bergambar diharapkan agar membantu guru dalam menjelaskan bahan ajar yang akan disampaikan serta dapat mendorong minat belajar siwa di kelas.

Dalam pembelajaran ilmu pengetahuan alam (IPA) dilaksanakan untuk memberikan pengalaman langsung kepada siswa serta pemahaman secara mendalam tentang lingkungan dan alam sekitar serta memiliki tujuan menumbuhkan kemampuan berpikir, sikap dan serta berkomunikasi antar siswa (Suryani, 2017). Dengan demikian pembelajaran ilmu pengetahuan alam (IPA) adalah suatu konsep atau tema yang dibahas dari berbagai aspek yang pembahasannya lebih efisien dan pencapaian tujuan pembelajaran juga diharapkan akan lebih efektif dan dapat terlatih untuk menemukan sendiri berbagai konsep yang dipelajari secara menyeluruh, bermakna, otentik dan aktif.

Salah satu media yang digunakan dalam pembelajaran materi jamur adalah kartu bergambar. Kartu bergambaratau biasa lebih dikenal dengan nama flash card adalah kartu kecil yang berisi gambar, teks atau tanda simbol yang mengingatkan atau menuntun siswa kepada sesuatu yang berhubungan dengan gambar itu (Astuti 2013). Media ini dibuat untuk mengatasi keterbatasan obyek maupun situasi sehingga proses pembelajaran berjalan dengan baik serta memberi gambaran tentang materi yang disampaikan oleh guru. Dengan adanya penggunaan media kartu bergambar diharapkan bisa memotivasi para siswa untuk meningkatkan kemampuan minat belajar siswa di sekolah. Menurut penelitian Winata dan Yuliani (2017) pemakaian media pembelajaran dalam proses belajar mengajar dapat membangkitkan keinginan dan minat yang baru, membangkitkan motivasi dan rangsangan kegiatan belajar, dan bahkan membawa pengaruhpengaruh psikologis terhadap siswa. Dengan demikian, penggunaan kartu bergambar akan sangat membantu siswa dalam meningkatkan keinginan belajar serta memungkinkan siswa untuk belajar mencari dan menyelesaikan suatu permasalahan berdasarkan minat mereka masing-masing.

Hasil observasi didapati bahawa pada pembelajaran IPA biologi tentang materi jamur seringkali siswa merasa kesulitan memahami pelajaran yang diberikan oleh guru, siswa kurang antusias dalam mengikuti pelajaran IPA biologi bahkan kurang diminati oleh siswa. Hal ini terjadi karena sebagian guru biologi masih menggunakan metode pembelajaran konvensional, dimana metode ini guru membacakan dan memberikan bahan yang disiapkan dan siswa hanya mendengarkan, mencatat serta menyelesaikan soal yang diberikan oleh guru.

Berdasarkan hasil analisis kebutuhan yang telah dilakukan dari angket yang diberikan kepada guru mata pelajaran biologi menunjukkan bahwa minimnya penggunaan media pembelajaran yang beragam dan keterbatasan waktu dalam mengembangkan sebuah media pembelajaran menjadi suatu masalah yang dihadapi para guru untuk mengembangkan media pembelajaran. Hal ini dapat dilihat dari hasil analisis kebutuhan yang diberikan kepada siswa menunjukkan sebanyak $71,42 \%$ media yang sering digunakan para guru berupa media buku cetak dalam proses pembelajaran. Pada saat guru menjelaskan materi siswa cenderung berbicara dengan 
teman sebangku dan membicarakan hal-hal yang tidak terkait dengan pelajaran dan tidak memperhatikan guru. Selain itu, pada saat guru bertanya kepada seluruh siswa, siswa lama sekali untuk menjawab pertanyaan guru. Siswa juga belum menunjukkan keberanian dalam mengemukakan pendapat di depan kelas. Hal tersebut jelas berpengaruh pada hasil belajar, dimana saat diberikan latihan soal siswa cenderung malas mengerjakan dan hasil belajar mereka kurang memuaskan.

Penggunaan media pembelajaran masih sangat sederhana, terkadang guru hanya menjelaskan secara teori tanpa menggunakan media sebagai perantara untuk menjelaska kosep yang diajarkan untuk siswa dapat mengerti dan memahami materi yang diajarkan. Kebiasaan ini sering menyebabkan kebiasaan belajar siswa yang hanya menghala teori saja tanpa satu media pendukung untuk lebih menjelaskan tentang konsep materi yang dipelajarinya. Untuk materi yang sulit seperti jamir guru hanya memberikanteori tanpa gambar yangmendukung untuk siswa bisa memhami dengan baik tentang jamur dan peranannya dalam kehidupan manusia.

Pada materi jamur menuntut siswa untuk mengetahui dan memahami keanekaragaman jamur beserta ciri-ciri jamur dan peranannya dalam kehidupan manusia sehingga sebanyak $67,85 \%$ siswa menganggap bahwa materi tersebut sulit untuk dipelajari. Oleh karena itu, sebanyak $75 \%$ siswa membutuhkan sebuah media yang memudahkan mereka dalam memahami materi yang dipelajari. Hal ini dilihat dari hasil analisis kebutuhan sebanyak $71,42 \%$ menginginkan guru harus kreatif dalam membuat sebuah media kartu bergambar yang dapat menarik perhatian siswa dalam mempelajari materi jamur. Minimnya pemahaman siswa tentang jamur menyebabkan proses pembelajaran yang berlangsung tidak maksimal serta penggunaan media yang tidak menarik perhatian siswa dalam pembelajaran membuat siswa tidak bersemangat dalam mengikuti pelajaran yang sedang berlangsung. Sehingga sebanyak 92,85\% membutuhkan media kartu bergambar dalam pelajaran biologi khususnya pada materi jamur. Tujuan Penelitian ini adalah untuk menghasilkan produk berupa media kartu gambar ini layak digunakan sebagai media pembelajaran.

\section{METODE PENELITIAN}

Jenis penelitian ini adalah penelitian pengembangan atau yang biasanya dikenal dengan Research and Development (R\&D) merupakan suatu proses yang mengembangkan dan memvalidasi suatu produk pendidikan

Berdasarkan acuan model pengembangan yang digunakan yaitu model ADDIE maka pengembangan mengikuti langkah-langkah yang diinstrusikan dalam model ADDIE tersebut. Langkah dalam pengembangan ini meliputi: 1) analisis yakni analisis kebutuhan, analisis media dan analisis lingkungan. 2) desain, desain yang dilakukan adalah merancang media kartu bergambar yang sifatnya konseptual. 3) Pengembangan meliputi mengembangkan media dalam bentuk kartu bergambar sesuai materi yang akan diajarkan. 4) melakukan uji coba, sebelum diuji coba akan melewati tahapan valiadasi oleh para validator antara lain, validasi materi, media dan desain. Setelah itu aan diujicobakan pada kelompok kecil dan kelompok besar untuk melihat dan mngukur tingkat kelayakan dari media yang dihasilkan. Jenis data yang digunakan dalam penelitian pengembangan ini adalah jenis data deskriptif kualitatif dan kuantitatif.Instrumen penelitian yang digunakan untuk keperluan pengembangan media kartu bergambar ini adalah angket. Angket dalam penelitian ini menggunakan skala Likert .

Analisis Data meggunakan rumus

$$
\text { Persentase }=\sum \frac{P}{N}
$$

\section{HASIL PENELITIAN}

Hasil pengembangan ini melewati tahapan analisis kebutuhan yani diperoleh bahwa siswa dan guru membutuhkan adanya pengembangan media ini, selanjutnya didesain dan divalidasi kemudian diujicobakan. Hasil pengembangan dapat dilihat pada Gambar 1. 


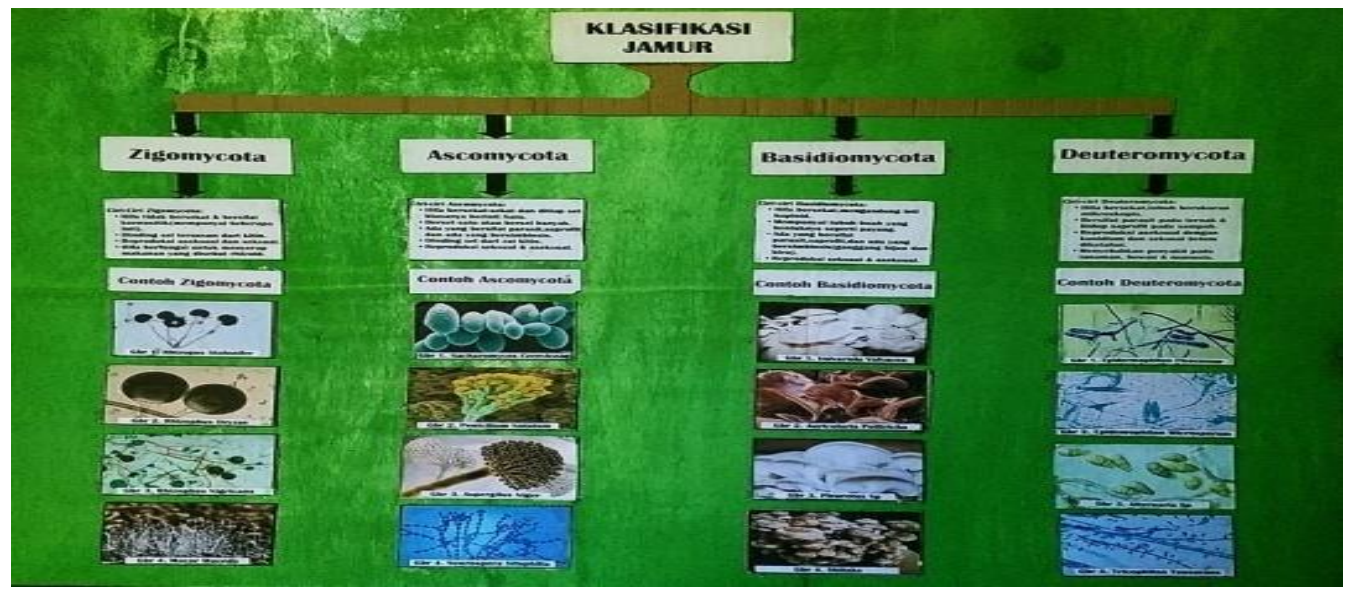

Gambar 1. Kartu bergambar

Berdasarkan hasil validasi dan uji coba diatas maka akan diuraikan seperti pada Tabel 1.

Tabel 1 Interpretasi Hasil Perhitungan Masing-Masing Uji Coba Produk

\begin{tabular}{lll}
\hline \multicolumn{1}{c}{ Subyek } & $\%$ & Kriteria \\
\hline Ahli Materi & 94 & Sangat Valid \\
\hline Ahli Desain & 94 & Sangat Valid \\
\hline Ahli Media & 97 & Sangat Valid \\
\hline Uji Coba Kelompok Kecil & 79 & Valid \\
\hline Uji Coba Kelompok Besar & 86 & Sangat Valid \\
\hline
\end{tabular}

Berdasarkan data para ahli dapat diketahui bahwa menurut ahli materi, ahli desain, ahli media, uji coba kelompok kecil, uji coba kelompok besar dengan jumlah persentase secara keseluruhan adalah $90 \%$ dan termasuk kategori sangat layak sehingga dapat diartikan bahwa media pembelajaran kartu bergambar secara keseluruhan sudah layak dan baik digunakan dalam proses pembelajaran dikelas yang dapat menarik perhatian siswa dalam belajar.

\section{PEMBAHASAN}

Penelitian pengembangan ini menghasilkan produk berupa media pembelajaran kartu bergambar tentang jamur yang dapat digunakan di SMP Negeri 16 Kota Kupang. Model pengembangan yang digunakan dalam penelitian ini adalah model pengembangan ADDIE dengan lima tahapan menurut Dick and Carey yaitu analisis, desain, pengembangan, implementasi dan evaluasi. Pada tahap terakhir yaitu tahap evaluasi tidak dipakai karena pengembangan media ini hanya sebatas uji coba, dan alasan lain juga karena pada tahap implementasi sudah dicantumkan skor penilaian kelayakan media, sehingga tahap evaluasi tidak di pakai.

Media pembelajaran kartu bergambar yang dikembangkan mengacu pada tahapan analisis yakni sesuai dengan kompetensi inti, kompetensi dasar serta tujuan pembelajaran yang diharapkan. Media kartu bergambar yang dikembangkan dibuat simple dan sederhana, alasannya untuk memenuhi kebutuhan peneliti dalam melakukan penelitian pada uji coba kelompok besar yang dibagi dalam dua kelompok yakni kelompok kecil dan kelompok besar dimana setiap kelompok kecil terdiri dari 4-5 orang siswa dan kelompok besar melibatkan seluruh siswa di dalam kelas. Media yang memiliki kesamaan tersebut dikembangkan dengan menggunakan alat dan bahan yang mudah didapat dan proses pembuatan media ini sangat mudah. Alat dan bahan yang disiapkan yaitu tripleks yang digunakan sebagai alas untuk meletakkan gambar jamur. Kartu gambar yang berbentuk segi empat yang terbuat dari bahan bekas kardus digunakan sebagai alat utuk menghasilkan gambar jamur. Kartu bergambar berbentuk segi empat berasal dari kertas karton yang akan menghasilkan gambar. Kartu gambar akan mewakili setiap materi jamur yang 
akan digunakan ketika berada dalam kelas. Media kartu gambar yang dikembangkan seperti pada gambar dibawah ini.

Setelah media kartu bergambar dikembangkan maka tahap berikutnya adalah menguji validitas atau kelayakan media kartu bergambar untuk menjadikan media pembelajaran yang layak digunakan di SMP Negeri 16 Kota Kupang. Ada tiga bagian penting yang dilihat pada tahap uji validasi ini yaitu uji validasi dari segi materi, uji validasi dari segi desain serta uji validasi dari segi media. Dari penyajian data hasil penilaian ahli materi, ahli desain serta ahli media yang telah dianalisis maka secara keakuratan media kartu bergambar ini berada pada standar kualifikasi sangat baik dan tidak perlu direvisi.

Hal ini dikarenakan persentase penilaian dari masing-masing ahli secara total diperoleh dari ahli materi $94 \%$, yang poin penilaiannya terdiri dari ( materi yang dipakai, kesesuaian media dengan materi, penyajian materi dan komponen yang digunakan, serta petunjuk penggunan media kartu bergambar), ahli desain 94\%, poin penilaiannya terdiri dari (kemenarikan desain media, kesesuaian media kartu gambar, ilustrasi dan sajian materi, pemilihan warna, ukuran, kecerahan, dan tampilan, serta petunjuk penggunan media permainan monopoli), dan ahli media $97 \%$, poin penilaiannya terdiri dari (penampilan fisik, kelengkapan komponen, kesesuaian media dengan siswa kelas Vllg, kesesuaian media dengan tujuan pembelajaran, ketepatan cara pengorganisasian, kesesuaian rancangan pembelajaran dengan media kartu gambar, serta petunjuk penggunan media kartu gambar). Setelah selesai melakukan uji validasi pada media pembelajaran kartu gambar maka peneliti melakukan uji kelompok kecil dan uji kelompok besar. Persentase penilaian hasil uji kelompok kecil diperoleh $79 \%$ dan uji kelompok besar diperoleh $86 \%$. Dengan demikian rata-rata persentase uji validasi, uji kelompok kecil dan uji kelompok besar adalah $90 \%$ dan berada pada standar kualifikasi sangat baik dan tidak perlu revisi. Hal ini disebabkan media pembelajaran kartu gambar yang dikembangkan memiliki kelebihan tersendiri.

Berdasarkan persentase uji validasi ahli materi 94\%, uji validasi ahli desain $94 \%$, uji validasi ahli media $97 \%$, uji kelompok kecil $79 \%$ dan uji kelompok besar $86 \%$, hasil penilaian tersebut dijumlahkan dan dibagi 5 sehingga menghasilkan total kelayakan sebesar $90 \%$ maka dapat disimpulkan bahwa media tersebut layak digunakan sebagai media pembelajaran di SMP Negeri 16 Kota Kupang Tahun Ajaran 2019/2020. Pengambilan keputusan tentang kelayakan media pembelajaran kartu gambar ini mengacu pada tingkat kualifikasi pencapaian menurut Riduwan (2016) yang mengatakan bahwa persentase yang diperoleh jika mencapai $\geq 61 \%$ maka media pembelajaran kartu gambar yang dikembangkan layak digunakan sebagai media pembelajaran. Hal ini menjadi alasan mengapa media kartu bergambar yang dikembangkan dari bahan sederhana layak digunakan karena persentase uji validasi ahli materi, uji validasi ahli desain, uji validasi ahli media, uji kelompok kecil dan uji kelompok besar memiliki total kelayakan $90 \%$ dan telah melebihi tingkat kualifikasi pencapaian $\geq 61 \%$.

\section{KESIMPULAN}

Berdasarkan rumusan masalah, tujuan pengembangan serta hasil penelitian yang telah dianalisis dan dibahas maka dapat disimpulkan bahwa:

1) Pada tahap analisis kebutuhan peserta didik diperoleh persentase sebesar $71,42 \%$ setuju jika media kartu gambar ini dikembangkan.

2) Pada uji validasi ahli materi $94 \%$, ahli desain $94 \%$, ahli media $97 \%$ serta uji coba kelompok kecil $79 \%$ da uji coba kelompok besar $86 \%$ maka dapat diperoleh total kelayaka sebesar $90 \%$,

Berdasarkan validasi ahli maupun uji coba kelayakan dengan memperoleh total kelayakan $90 \%$ maka dapat disimpulkan bahwa media kartu gambar ini layak digunakan sebagai media pembelajaran karena melebihi tingkat kualifikasi pencapaian $\geq 61 \%$

\section{SARAN}

Penelitian dan pengembangan media kartu bergambar ini telah selesai dilakukan sehingga diharapkan kepada: 
a. Guru dapat menggunakan media pembelajaran ini dengan rancangan model pembelajaran yang sesuai.

b. Siswa dapat melatih diri dalam belajar IPA pokok bahasan jamur dengan menggunakan media kartu gambar.

c. Peneliti selanjutnya agar melakukan penelitian Implementasi tentang pengaruh dan efektifitas media kartu bergambar dengan mengaitkan seluruh pokok bahasan jamur

\section{DAFTAR PUSTAKA}

Apriliani, H., Mashudi, \& Aminuyati. 2013. Pengaruh Penggunaan Media Visual Terhadap Hasil Belajar Siswa Pada Mata Pelajaran Ekonomi Di SMA. Jurnal Pendidikan Dan Pembelajaran Khatulistiwa 2(7) : 1-11

Astuti, W., Yeni, L.F., \& Aryati, E. 2013. Pengaruh Media Kartu Bergambar Terhadap Hasil Belajar Siswa Pada Materi Jamur di SMA. Jurnal Pendidikan dan Pembelajaran Khatulistiwa 2 (9) : $1-10$

Azhar, A. 2016. Media Pembelajaran Edisi Revisi. Jakarta: PT. Raja Grafindo Persada.

Nugroho, M. R., Kriswandani, \& Prihatnani, E. 2013. Pengaruh Media Permainan Kartu Kucingan Terhadap Hasil Belajar Siswa Kelas VII SMP Negeri 03 Getasan Kabupaten Semarang Tahun Ajaran 2013/2014. Salatiga: Universitas Kristen Satya Wacana

Prayogo, D., Haenilah, E.Y., \& Sugiyanto. 2015. Pengaruh Penggunaan Media Kartu Bergambar Terhadap Hasil Belajar IPA Siswa Kelas V. Bandar Lampung: Universitas Lampung.

Riduwan. 2016. Skala Pengukuran Variabel-Variabel Penelitian. Bandung: Alfabeta.

Sadiman, A.S, Rahardjo, R., Haryono, A. \& Harjito. 2012. Media Pendidikan: Pengertian, Pengembangan, Dan Pemanfaatannya. Jakarta: PT Grafindo Persada.

Suryani. 2017. Pengaruh Media Kartu Bergambar Melalui Model Pembelajaran Examples Non Examples Terhadap Keterampilan Berpikir Kritis Dan Afektif Peserta Didik Pada Materi Pokok Ekosistem. Lampung: Institut Agama Islam Negeri Raden Intan.

Winata, H. \& Yuliani, K. 2017. Media Pembelajaran Mempunyai Pengaruh Terhadap Motivasi Belajar Siswa. Jurnal Pendidikan Manajemen Perkantoran 2(1) : 27-33. Doi : https://doi.org/10.17509/jpm.v2i1.14606 